\title{
Information Needs of Dairy Farm Women in Nainital District of Uttarakhand
}

\author{
Arpita Sharma ${ }^{1 *}$, Sunil Kumar² and Naresh Kumar Kandpal ${ }^{3}$ \\ ${ }^{1}$ Assistant Professor, Dept. of Agricultural Communication, College of Agriculture, GBPUA\&T, Pantnagar, Uttarakhand, India \\ ${ }^{2}$ Assistant Professor, Department of Animal Genetics and Breeding, College of Veterinary and Animal Sciences, GBPUA\&T, \\ Pantnagar, Uttarakhand, India \\ ${ }^{3}$ Beauro Chief of Hindustan News paper, Uttarakhand, India
}

"Corresponding author: sharmaarpita615@gmail.com

Received: 24 Jan., $2020 \quad$ Revised: 22 Apr., $2020 \quad$ Accepted: 03 June, 2020

\begin{abstract}
Dairy farming is one of the prominent enterprises, which supports the rural households by providing profitable employment and steady income. Dairy farming is an integral part of homestead farming system. In hill areas dairy farming is totally dependent on women. Many research studies have indicated that women in hill areas are unaware about many aspects. Thus, present research investigation was conducted in Jeoli, Bhaluti, Sariyatal and Kausani villages of Bhimtal block of Nainital district to assess the needs of hill women engaged in dairy farming. The study revealed that majority of respondents belonged to middle age group category and belonged to General caste. They were educated upto primary level. Majority of respondents were involved in dairy farming and farming and have 3-7 nali. All the farmers owned Mobile Phone and television. Majority of respondents have Cow, buffalo and goats. Majority of respondents were unaware about feeding schedule for milch animal, feeding schedule for young heifer, feeding schedule for pregnant animal, time and frequency of feeding, information on mineral mixture, formulation of ration, complete feed block, feeding schedule for young calves, colostrums feeding for new born calf, selection of breed, high yielding breed, pregnancy diagnosis, gestation period, suitable cross breed to their region, selection of adult of Bull or Semen, age of breedable heifer, selection of milch animal, castration of scrub bulls, care and management of new born calf, milking methods, vaccination schedule, knowledge about disease, control of external parasite, deworming practice, disinfection of shed, disposal of dead animal, treatment against contagious disease, precaution against parasitic disease, sterility treatment, Govt programme for Dairy farming etc.
\end{abstract}

Keywords: Dairy, women, information need

India is an agrarian country where more than half of the Indian population is engaged in agriculture as well as on livestock for livelihood. However, the contribution of agriculture to the Gross Domestic Product of the Nation is continually shrinking. It has declined from 36.4 per cent in 1982-83 to 13.7 per cent in 2012-13 (Economic Times, 2013). According to Singh et al (2016), in addition to the exponential growth of industrial and service sector, lack of an adequate information on various aspects of dairy and farming can be attributed as one of the

How to cite this article: Sharma, A., Kumar, S. and Kandpal, N.K.
(2020). Information Needs of Dairy Farm Women in Nainital District
of Uttarakhand. International Journal of Inclusive Development, 6(1):
17-22.
Source of Support: None; Conflict of Interest: None 
reasons for this. In India, women's involvement in livestock management is a longstanding tradition and dairy farming has been an integral part of homestead farming system (Kumari et al. 2015). Various research investigations revealed that rural women play a significant role in livestock rearing but they are unaware about many aspects related to livestock and dairy farming. Thus, present research investigation was conducted with two major objectives:

1. To study the socio-economic characteristics of hill women engaged in dairy farming.

2. To assess the needs of hill women engaged in dairy farming.

\section{MATERIALS AND METHODS}

Present research investigation was conducted on 100 hill women in three villages viz; Kausani, Sariyatal and Jeoli of Bhimtal block in Nainital District of Uttarakhand. Data was collected in the month of October-November 2017. Data was collected with semi-structured interview schedule containing information about Socio-economic, communication characteristics and information needs of dairy farming.

\section{RESULTS AND DISCUSSION}

The results of the present study as well as relevant discussion have been summarized under following heads:

\section{Socio-Economic Characteristics of dairy farm} women: Table 1 clearly revealed the socio-economic characteristics of women engaged in dairy farming. Majority of respondents (50 per cent) belonged to middle age group category (25-35 year) followed by old age group category (32 per cent) and young age group category (18 per cent). These findings are in line with the findings of Rani and Subhadra (2009). Majority of respondents (94 per cent) belonged to General caste followed by Schedule caste (2 per cent) and Other Backward Caste (4 per cent). Majority of respondents (60 per cent) were educated up to primary level followed by high school (18 per cent) and very few (only 8 per cent) respondents were educated up to intermediate level. Majority of respondents were involved in dairy farming and farming ( 80 per cent) followed by bee keeping and dairy farming (16 per cent) and Shop keepers with dairy farming (4 per cent). Majority of respondents (72 per cent) have 3-7 nali followed by $>7$ nali (14 per cent) and $<3$ nali (10 per cent) cultivable land.

Data clearly revealed that majority of respondents were of middle age group, belonged to general caste have primary level of education. They were engaged in Dairy as well as other occupation and have 3-7 nali cultivable land.

Table 1: Distribution of respondents according to socio-economic characteristics of dairy farm women

\begin{tabular}{|c|c|c|}
\hline Category & Respondents & Per Centage \\
\hline \multicolumn{3}{|l|}{ Age } \\
\hline Young (20-25) & 18 & 18 \\
\hline Middle (25-35) & 50 & 50 \\
\hline Old (Above 35) & 32 & 32 \\
\hline \multicolumn{3}{|l|}{ Caste } \\
\hline General & 94 & 94 \\
\hline Other Backward & 4 & 4 \\
\hline $\begin{array}{l}\text { Schedule Caste and } \\
\text { Schedule Tribe }\end{array}$ & 2 & 2 \\
\hline \multicolumn{3}{|l|}{ Education } \\
\hline Illiterate & 14 & 14 \\
\hline Primary level & 60 & 60 \\
\hline High school & 18 & 18 \\
\hline Intermediate & 8 & 8 \\
\hline \multicolumn{3}{|l|}{ Occupation } \\
\hline Dairy farming and Farming & 80 & 80 \\
\hline $\begin{array}{l}\text { Bee Keeping and dairy } \\
\text { farming }\end{array}$ & 16 & 16 \\
\hline $\begin{array}{l}\text { Shop keepers with dairy } \\
\text { farming }\end{array}$ & 4 & 4 \\
\hline \multicolumn{3}{|l|}{ Size of land holding (nali) } \\
\hline$>3$ cultivable land & 10 & 10 \\
\hline 3-7 cultivable land & 72 & 72 \\
\hline $7<$ cultivable land & 14 & 14 \\
\hline
\end{tabular}

Animal Husbandry activities undertaken: Findings in Table 2 indicated that majority of respondents have buffalo ( 50 per cent) followed by cow (38 per cent). Less than half per cent respondents have goats (36 per cent). Majority of respondents (64 per cent) reported that their animal provides $>3$ litter per day milk followed by 3-6 litter (20 per cent). Majority of respondents (62 per cent) reported that their animal's milk sale of ₹ 30 milk followed by ₹ 30-35 (30 per cent). Only 8 per cent respondents reported that milk sale of ₹ 35-42 (8 per cent). Majority of respondents earn income ₹ 1000-3000 per month followed by $>1000$ (30 per cent respondents) and 
$3000<$ (8 per cent respondents). A similar finding was reported by Narmatha et al. (2009) that majority of respondents have buffalo, cow and goats.

Thus, it may be inferred that, most of the respondents had buffalo, goats and male cattle. Majority of respondents' sale milk of their animal of ₹ 30 and they earn ₹ 1000-3000 per month.

Table 2: Distribution of respondents according to animal husbandry activities undertaken

\begin{tabular}{|c|c|c|}
\hline Animal & Respondents & Per Centage \\
\hline \multicolumn{3}{|c|}{ Type of Animal } \\
\hline Cow & 38 & 38 \\
\hline Buffalo & 50 & 50 \\
\hline Goats & 36 & 36 \\
\hline Male cattle & 9 & 9 \\
\hline \multicolumn{3}{|c|}{ Type of breed } \\
\hline Deshi & 98 & 98 \\
\hline Holeston & 2 & 2 \\
\hline \multicolumn{3}{|c|}{ Yield (Milk Litter/Day) } \\
\hline$>3$ & 64 & 64 \\
\hline $3-6$ & 20 & 20 \\
\hline $6<$ & 16 & 16 \\
\hline \multicolumn{3}{|c|}{ Sale of milk (₹) } \\
\hline$>30$ & 62 & 62 \\
\hline $30-35$ & 30 & 30 \\
\hline $35-42$ & 8 & 8 \\
\hline \multicolumn{3}{|c|}{$\begin{array}{c}\text { Income Generated (₹ Per } \\
\text { month) }\end{array}$} \\
\hline$>1000$ & 30 & 30 \\
\hline $1000-3000$ & 62 & 62 \\
\hline $3000<$ & 8 & 8 \\
\hline
\end{tabular}

\section{Information Need Assessment of Dairy Farmers}

Nutrition and Feeding: Under this head respondents were asked if they were aware of Nutrition and Feeding: [1] Feeding schedule for milch animal [2] Feeding schedule for young heifer [3] Feeding schedule for pregnant animal [4] Time and frequency of feeding [5] Information on mineral mixture [6] Formulation of ration [7] Complete feed block [8] Feeding schedule for young calves [9] Colostrums feeding for new born calf.

It is evident from the table that out of total number of respondents, majority of them (76 per cent) were unaware about feeding schedule for milch animal while only 24 per cent of the respondents were aware about the same. Majority of respondents (82 per cent) were unaware about feeding schedule for young heifer while 18 per cent respondents were aware about the same. Total 70 per cent respondents were unaware about feeding schedule for pregnant animal while 30 per cent respondents were aware about the same. More than half per cent of the respondents (58 per cent) were unaware about time and frequency of feeding while 42 per cent people were reported that they were aware about the time and frequency of feeding. Majority of respondents (74 per cent) were not aware about the information on mineral mixture while remaining 26 per cent respondents stated that they were aware about mineral mixture. More than fifty per cent of the respondents (60 per cent) were not aware about formulation of ration while 40 per cent respondents were aware about the same. Total 72 per cent respondents were not aware about complete feed block while 28 per cent respondents were aware about the same. More than half per cent of the respondents (66 per cent) were unaware about the feeding schedule for young calves while 34 per cent of the respondents were aware about the same. Majority of respondents (78 per cent) were unaware about colostrums feeding for new born calf while 22 per cent respondents were aware about the same.

Breeding and Reproduction: This head comprised of eleven components which were [1] Selection of breed [2] High Yielding breed [3] Heat Detection [4] Artificial Insemination [5] Pregnancy Diagnosis [6] Gestation period [7] Suitable Cross breed to their region [8] Selection of adult of Bull or Semen [9] Age of breedable heifer [10] Selection of milch animal [11] Castration of scrub bulls.

It can be conclude from the table that total 90 per cent respondents were not aware about selection of breed while on the other hand 10 per cent respondents were aware about the same. Total 88 per cent respondents were unaware about high yielding breed while 12 per cent respondents reported that they were aware about the same. Majority of respondents (88 per cent) reported that they were not aware about pregnancy diagnosis while 12 per cent respondents were aware about pregnancy diagnosis. Total 82 per cent respondents were not aware about gestation period and 18 per cent respondents were aware about gestation period. Total 78 per cent respondents reported 
that they were unaware about suitable cross breed to their region but 22 per cent people were aware about suitable cross breed to their region. Majority of respondents (90 per cent) reported that they were not aware about selection of adult of bull or semen while 10 per cent respondents were aware about the same. Majority of respondents (84 per cent) reported that they were unaware about age of breedable heifer while 16 per cent respondents were aware about the same. Total 82 per cent respondents were not aware about the selection of milch animal and 18 per cent respondents were aware about the same. Majority of respondents were (86 per cent) were not aware about castration of scrub bulls and remaining 14 per cent respondents were aware about castration of scrub bulls.

General Management: This head comprised of three components which were: [1] Clean Milk production [2] Care and management of new born calf [3] Milking methods. The data presented in table 3 depicts that more than half per cent respondents (58 per cent) were unaware about clean Milk production while remaining 42 per cent respondents were aware about the same. Total 56 per cent respondents were not aware about care and management of new born calf but 44 per cent respondents were know about the same. Maximum number of respondents (82 per cent) reported that they do not know about milking methods while 18 per cent respondents were aware about the same.

Health Care Management: This head comprised of nine components which were: [1] Vaccination schedule [2] Knowledge about disease [3] Control of external parasite [4] Deworming practice [5] Disinfection of shed [6] Disposal of dead animal [7] Treatment against contagious disease [8] Precaution against parasitic disease [9] Sterility treatment. Maximum 84 per cent respondents were not aware about vaccination schedule while 16 per cent respondents were aware about the same. Total 78 per cent respondents reported that they were unaware about knowledge about disease while 22 per cent respondents were aware about the same. Total 56 per cent respondents were not aware about control of external parasite while 44 per cent respondents were aware about the same. Total 74 per cent respondents reported that they were unaware about deworming practice while remaining 26 per cent respondents were aware about the same.
Total 72 per cent respondents were aware about Disinfection of shed while 28 per cent respondents were not aware about the same. Total 62 per cent respondents were unaware about disposal of dead animal while 38 per cent respondents were aware about the same. Total 58 per cent respondents do not know about treatment against contagious disease while 42 per cent respondents were aware about the same. Maximum number of respondents (78 per cent) reported that they were aware about precaution against parasitic disease while 22 per cent respondents were aware about the same. Majority of respondents (76 per cent) reported that they were aware about Sterility treatment while 24 per cent respondents were aware about the same.

Fodder production: This head comprised of six components which were: [1] Fodder crops and its cultivation [2] Crop rotation [3] Making of urea treatment of straw [4] Conservation of fodder [5] Drying of fodder crops [6] Silage making.

Under fodder production head, total 36 per cent respondents were unaware about fodder crops and its cultivation while 64 per cent were aware about the same. Total 70 per cent respondents reported that they were aware about crop rotation while 30 per cent respondents were aware about the same. More than fifty per cent ( 66 per cent) respondents reported that they were not aware about Making of urea treatment of straw while remaining respondents ( 34 per cent) were aware about the same. Total 60 per cent respondents were aware about conservation of fodder while 40 per cent respondents were not aware about the same. Total 66 per cent respondents were aware about drying of fodder crops while 34 per cent respondents reported that they were not aware about the same. Maximum number of respondents (76 per cent) reported that they were unaware about Silage making while 24 per cent respondents were aware about the same.

Others: Maximum number of respondents (94 per cent) were not aware about support provided through Government while 6 per cent respondents were aware about the same. Maximum number of respondents (98 per cent) reported that they were not aware about Knowledge of Govt programme for dairy farming while only 2 per cent respondents were aware about the same. 
Table 3: Information need assessment regarding dairy farming

\begin{tabular}{|c|c|c|c|}
\hline S1. No. & Statement & Aware & Unaware \\
\hline 1. & Nutrition and Feeding & & \\
\hline (a) & Feeding schedule for milch animal & $24(24 \%)$ & $76(76 \%)$ \\
\hline (b) & Feeding schedule for young heifer & $18(18 \%)$ & $82(82 \%)$ \\
\hline (c) & Feeding schedule for pregnant animal & $30(30 \%)$ & $70(70 \%)$ \\
\hline (d) & Time and frequency of feeding & $42(42 \%)$ & $58(58 \%)$ \\
\hline (e) & Information on mineral mixture & $26(26 \%)$ & $74(74 \%)$ \\
\hline (f) & Formulation of ration & $40(40 \%)$ & $60(60 \%)$ \\
\hline (g) & Complete feed block & $28(28 \%)$ & $72(72 \%)$ \\
\hline (h) & Feeding schedule for young calves & $34(34 \%)$ & $66(66 \%)$ \\
\hline (i) & Colostrums feeding for new born calf & $22(22 \%)$ & $78(78 \%)$ \\
\hline 2. & Breeding and Reproduction & & \\
\hline (a) & Selection of breed & $10(10 \%)$ & $90(90 \%)$ \\
\hline (b) & High Yielding breed & $12(12 \%)$ & $88(88 \%)$ \\
\hline (c) & Heat Detection & $22(22 \%)$ & $78(78 \%)$ \\
\hline (d) & Artificial Insemination & $18(18 \%)$ & $82(82 \%)$ \\
\hline (e) & Pregnancy Diagnosis & $12(12 \%)$ & $88(88 \%)$ \\
\hline (f) & Gestation period & $18(18 \%)$ & $82(82 \%)$ \\
\hline (g) & Suitable Cross breed to their region & $22(22 \%)$ & $78(78 \%)$ \\
\hline (h) & Selection of adult of Bull or Semen & $10(10 \%)$ & $90(90 \%)$ \\
\hline (i) & Age of breedable heifer & $16(16 \%)$ & $84(84 \%)$ \\
\hline (j) & Selection of milch animal & $18(18 \%)$ & $82(82 \%)$ \\
\hline$(\mathrm{k})$ & Castration of scrub bulls & $14(14 \%)$ & $86(86 \%)$ \\
\hline 3. & General Management & & \\
\hline (a) & Clean Milk production & $42(42 \%)$ & $58(58 \%)$ \\
\hline (b) & Care and management of new born calf & $44(44 \%)$ & $56(56 \%)$ \\
\hline (c) & Milking methods & $18(18 \%)$ & $82(82 \%)$ \\
\hline 4. & Health Care Management & & \\
\hline (a) & Vaccination schedule & $16(16 \%)$ & $84(84 \%)$ \\
\hline (b) & Knowledge about disease & $22(22 \%)$ & $78(78 \%)$ \\
\hline (c) & Control of external parasite & $44(44 \%)$ & $56(56 \%)$ \\
\hline (d) & Deworming practice & $26(26 \%)$ & $74(74 \%)$ \\
\hline (e) & Disinfection of shed & $28(28 \%)$ & $72(72 \%)$ \\
\hline (f) & Disposal of dead animal & $38(38 \%)$ & $62(62 \%)$ \\
\hline (g) & Treatment against contagious disease & $42(42 \%)$ & $58(58 \%)$ \\
\hline (h) & Precaution against parasitic disease & $22(22 \%)$ & $78(78 \%)$ \\
\hline (i) & Sterility treatment & $24(24 \%)$ & $76(76 \%)$ \\
\hline 5. & Fodder production & & \\
\hline (a) & Fodder crops and its cultivation & $64(64 \%)$ & $36(36 \%)$ \\
\hline (b) & Crop rotation & $30(30 \%)$ & $70(70 \%)$ \\
\hline (c) & Making of urea treatment of straw & $34(34 \%)$ & $66(66 \%)$ \\
\hline (d) & Conservation of fodder & $60(60 \%)$ & $40(40 \%)$ \\
\hline (e) & Drying of fodder crops & $66(66 \%)$ & $34(34 \%)$ \\
\hline (f) & Silage making & $24(24 \%)$ & $76(76 \%)$ \\
\hline 6. & Other & & \\
\hline (a) & Support provided through Government & $6(6 \%)$ & $94(94 \%)$ \\
\hline (b) & Knowledge of Govt programme for Dairy farming & $2(2 \%)$ & $98(98 \%)$ \\
\hline
\end{tabular}




\section{CONCLUSION}

Hill women play a very important role in dairy farming. The present study concluded that majority of the women engaged in dairy farming were of middle age group belonged to general caste and educated upto primary level. Majority of respondents have cow as major animal and gives 3-6 liter milk per day and income generation is ₹ 3000-6000 per month. Majority of respondents were unaware about many aspects related to dairy farming. Thus, there is an urgent need to develop a participatory extension strategy to aware the dairy women on many aspects.

\section{REFERENCES}

Durgga Rani, V. and Subhadra, M.R. 2012. Training needs of farm women in dairy farming, Veterinary World, 2(6): 221-223.
Economic Times. 2013. Agriculture's share in GDP declines to $13.7 \%$ in 2012-13. August 30, 2013.

Farinde, A.J. and Ajayi, A.O. 2005. Training needs of women farmers in livestock production: Implies for rural development in Oyo state of Nigeria. J. Soc. Sci., 10: 159164.

Kumari, S., Sethi, N., Malik, J.S. and Yogi, V. 2015. Need Assessment of Women Dairy Farmers. Advances in Social Research, 1(1): 35-42.

Narmatha, N., Uma, V., Arun, L. and Geetha, R. 2009. Level of participation of women in livestock farming activities. Tamil Nadu J. Vet. Sci., 5: 4-8.

Sethi, N. 2010. Factors affecting adoption of scientific technologies by dairy women in buffaloes. Proc. of International Buffalo Conference, 2: 166-67.

Singh, N., Malhotra, P. and Singh, J. 2016. Information needs and seeking behaviour of dairy farmers of Punjab. Indian J. Dairy Sci., 69(1). 